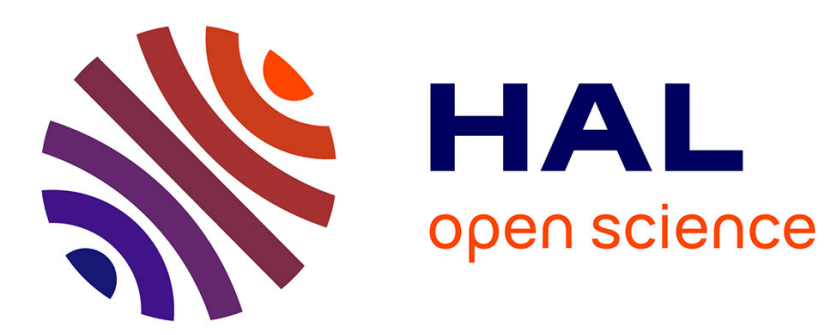

\title{
Trout Sertoli and Leydig cells: isolation, separation, and culture
}

Maurice Loir

\section{To cite this version:}

Maurice Loir. Trout Sertoli and Leydig cells: isolation, separation, and culture. Gamete research, 1988, 20, pp.437-458. 10.1002/mrd.1120200406 . hal-02728260

\section{HAL Id: hal-02728260 \\ https: / hal.inrae.fr/hal-02728260}

Submitted on 2 Jun 2020

HAL is a multi-disciplinary open access archive for the deposit and dissemination of scientific research documents, whether they are published or not. The documents may come from teaching and research institutions in France or abroad, or from public or private research centers.
L'archive ouverte pluridisciplinaire HAL, est destinée au dépôt et à la diffusion de documents scientifiques de niveau recherche, publiés ou non, émanant des établissements d'enseignement et de recherche français ou étrangers, des laboratoires publics ou privés. 


\title{
Trout Sertoli and Leydig Cells: Isolation, Separation, and Culture
}

\author{
Maurice Loir \\ Physiologie des Poissons, INRA, Campus de Beaulieu, F 35042 Rennes Cedex, France
}

\begin{abstract}
Trout testes at various stages of maturation were dissociated by perfusion at $12^{\circ} \mathrm{C}$ with collagenase plus pronase and then with collagenase alone, followed by slight shaking overnight in $1 \%$ bovine albumin. This step provided a suspension of isolated somatic and germ cells, clusters of interstitial cells, and either intact spermatogenetic cysts (meiotic testes) or clusters of Sertoli cells (other testes). Most of the spermatozoa were removed from the testis cell suspension by centrifugation in Percoll (density $1.065 \mathrm{~g} / \mathrm{ml}$ ). Sertoli and Leydig cells were prepared by a two-step separation method: 1) the testis cell suspension was separated by sedimentation at unit gravity into "isolated cell" and "cell cluster" populations; 2) these populations were fractionated by isopyknic centrifugation in Percoll gradients. In terms of somatic cell composition, a nearly pure Sertoli cell (clusters) population was obtained between 1.017 and $1.033 \mathrm{~g} / \mathrm{ml}$ and a Leydig cell (clusters) enriched population of between 1.033 and $1.048 \mathrm{~g} / \mathrm{ml}$ (testes resuming spermatogenesis) or 1.048 and $1.062 \mathrm{~g} / \mathrm{ml}$ (other testes).

These various cell populations were cultured in modified Leibovitz L15 medium for 10-15 days. When seeded, the Sertoli cells had a normal ultrastructure that remained unchanged for at least 10 days, and the steroidogenic activity of Leydig cells could be stimulated by salmon gonadotropin. Leydig cells remained $3 \beta$-HSD positive and produced progesterone and $17 \alpha, 20 \beta-\mathrm{OH}$ progesterone for at least 11 days.

This study points out that viable and differentiated trout somatic testicular cells can be prepared and cultured for several days.
\end{abstract}

Key words: salmonid, testis, sertoli cell, leydig cell, cell separation, cell culture

\section{INTRODUCTION}

The testis of teleost fish (such as Salmonids) which breed seasonally, is an excellent model for studying the control of steroidogenesis and spermatogenesis. Testis maturation is spread over several months and is relatively synchronous. Furthermore, a single type of pituitary hormones, maturational gonadotropin (GTH), controls the whole steroidogenic activity of the testis [Idler and $\mathrm{Ng}, 1983$ ].

Our knowledge of the endocrine control of spermatogenesis in teleost fish, trout

Received October 2, 1987; accepted February 19, 1988.

Address reprint requests to M. Loir, Physiologie des Poissons, INRA, Campus de Beaulieu, F35042, Rennes Cedex, France.

(C) 1988 Alan R. Liss, Inc. 
in particular, has greatly advanced over the last 20 years [for review, see Billard et al., 1982; Fostier et al., 1983]. Most information has come from measurements of hormone levels in the peripheral blood, injection of pituitary extracts, gonadotropins, and steroids into either intact or hypophysectomized fish and from some in vitro studies using either organotypic cultures or chopped tissues [Billard et al., 1982; Harbin, 1984]. However, such investigations are difficult to interpret because of complex feedback control mechanisms between the gonads and the hypothalamopituitary axis, extratesticular sources of steroids, and possible interactions between the various testis cell types. At present, some of the most interesting questions dealing with the local regulation of spermatogenesis include the following: Which testis cells are targets for GTH? Do Sertoli cells have a steroidogenic activity? How is the action of steroids that control spermatogenesis and spermiation mediated? Are Sertoli cells targets for these steroids? Do the seminiferous lobules (Sertoli and germ cells) modulate Leydig cell function, as is now well evidenced in mammals [Tahka, 1986]? Do other pituitary hormones or factors participate in the control of steroidogenesis and gametogenesis?

To answer these questions, it is necessary to apply in vitro techniques to fish using populations of isolated testicular cells, which already have been proved very useful in mammals. Trout testis cells already have been separated by velocity sedimentation after mechanical dispersion of testis [Iatrou et al., 1978]. However, only germ cells, together with very few Sertoli cells, were obtained.

In this paper we propose the following: 1) an enzymatic method to disperse one trout testis with a high yield for somatic cells; 2) a two-step separation method to prepare a nearly pure Sertoli cell population and a very enriched Leydig cell population; 3) a culture medium for culturing viable and metabolically active testis somatic cells for several days.

\section{MATERIALS AND METHODS Animals}

Males of summer-spawning, autumn-spawning, and spring-spawning strains of rainbow trout, 1 to 3 years old and weighing 400 to $1900 \mathrm{~g}$, were employed. They were kept in recycled fresh water at $12-15^{\circ} \mathrm{C}$ under a natural photoperiod.

\section{Solutions}

The following solutions containing $100 \mathrm{U} / \mathrm{ml}$ penicillin, $100 \mu \mathrm{g} / \mathrm{ml}$ streptomycin, and $2.5 \mu \mathrm{g} / \mathrm{ml}$ kanamycin were used: Swim S-77 medium containing $\mathrm{Mg}++$ but not $\mathrm{Ca}++$ was employed for the enzymatic dissociation of testes; L15 Leibovitz medium was used routinely for all the following steps of testis dissociation, cell separation, and culture. These media were supplemented with $4 \mathrm{mM} \mathrm{Na}$ lactate, 2 $\mathrm{mM}$ glutamine, $10 \mu \mathrm{M}$ retinyl acetate, $20 \mu \mathrm{M}$ tocopherol acetate and $5 \mu \mathrm{g} / \mathrm{ml}$ ascorbic acid. In addition, the Swim medium was supplemented with $20 \mathrm{mM} \mathrm{NaCl}$, $0.15 \mathrm{mM} \mathrm{KH}_{2} \mathrm{PO}_{4}, 10 \mathrm{mM}$ Hepes, and $1 \mathrm{mM}$ Na pyruvate. The $\mathrm{pH}$ of the two media was adjusted to 7.7 . A $0.8 \mathrm{mg} / \mathrm{ml}$ collagenase solution (Boerhinger; from Clostridium histolyticum) and a $1 \mathrm{mg} / \mathrm{ml}$ pronase solution (Boehringer) were prepared in modified Swim medium, and their osmotic pressure was adjusted to $315 \mathrm{mOsM}$. 


\section{Preparation of Testis Cell Suspensions}

All operations until and including culture were carried out at $12^{\circ} \mathrm{C}$ in sterile conditions.

Fish were anesthetized with $3 \%$ phenoxyethanol, placed on a surgical board, and swabbed on the ventral surface with $63 \%$ ethanol. Testes were removed aseptically. Testis weight varied from $0.7 \mathrm{~g}$ at maturation stage II to $20 \mathrm{~g}$ at maturation stages VII and VIII. Maturation stages were determined first by testes appearance and then, after testis dissociation, from the germ cell population according to Billard and Escaffre [1975].

The testis was washed with $20 \mathrm{ml}$ of modified Swim medium. The deferent duct was cut at the posterior end of the testis. A thin polyethylene catheter connected to a syringe containing collagenase solution was inserted into the testicular vein at the anterior extremity of the testis, and another catheter, connected to a syringe containing $4 \mathrm{ml}$ of pronase solution, was inserted into the main duct. The vein and main duct were firmly tightened around the catheters. The two lateral margins of the testis were cut with fine scissors to allow the outflow of the medium, which was to be injected into the catheters. The testis was laid in a perspex chamber (length: 110 $\mathrm{mm}$, width: $30 \mathrm{~mm}$, depth: $18 \mathrm{~mm}$ ) containing $40 \mathrm{ml}$ collagenase solution. The contents of the two syringes were injected slowly. Then the catheters were disconnected from the syringes and connected, through a peristaltic pump, to a pipe so that the medium present in the chamber could be continuously pumped and reinjected into the testis. After 1 hour perfusion at a rate progressively increasing from 0.25 to $1 \mathrm{ml} / \mathrm{min}$, the enzyme solution was replaced by $40 \mathrm{ml}$ collagenase solution. Three to five hours later the solution was replaced by $40 \mathrm{ml}$ modified Swim medium (osmotic pressure: $315 \mathrm{mOsm}$ ). After 1 hour the testis was transferred to a Petri dish containing $20 \mathrm{ml} \mathrm{1 \%} \mathrm{bovine} \mathrm{serum} \mathrm{albumin} \mathrm{(BSA,} \mathrm{IBF} \mathrm{France;} \mathrm{osmotic}$ pressure: $307 \mathrm{mOsM}$ ). The catheters, the wall of the main duct, and the largest blood vessels were removed. The testis was gently cut in several pieces and then transferred with a large-bore $10 \mathrm{ml}$ pipette into a $800 \mathrm{ml}$ Falcon culture flask containing either $150 \mathrm{ml}$ of $1 \%$ BSA solution (mature testes) or only $100 \mathrm{ml}$ (other testes). The cell suspension was left overnight at $12^{\circ} \mathrm{C}$ with light shaking. Finally, the suspension was pipetted three to four times with a small-bore $20 \mathrm{ml}$ pipette, and the remaining testis fragments were removed by filtration on a $150 \mu \mathrm{m}$ nylon filter.

When present, spermatozoa were removed as much as possible from the cell suspension by the following low-speed, iso-density Percoll centrifugation method. Sterile stock iso-osmotic Percoll (SIP) solution ( $\mathrm{pH} 7.70,305$ mOsM) was prepared by mixing nine volumes of commercial Percoll (Pharmacia) with 1 volume of $8.4 \times$ M 199 medium containing 1\% BSA and $200 \mathrm{mM}$ Hepes. The SIP solution $(25 \mathrm{ml})$ was added to either six (mature testes) or four (other testes) $50 \mathrm{ml}$ Falcon conical-shaped centrifuge tubes, and $24 \mathrm{ml}$ of the testis cell suspension was added to each tube and homogeneously mixed with the SIP solution (resulting mean density: $1.065 \mathrm{~g} / \mathrm{ml}$ ). After centrifugation at $500 \mathrm{~g}$ for 30 minutes at $12^{\circ} \mathrm{C}$, the upper $10 \mathrm{ml}$ of each tube were pipetted and pooled. This cell suspension was diluted seven times with modified Leibovitz L15 medium (osmotic pressure adjusted to $300 \mathrm{mOsM}$ ) and centrifuged at $200 \mathrm{~g}$ for 15 minutes. The pellets were washed again in the same way. If further cell separation was planned, the pellets then were resuspended in modified L15 medium: $25 \mathrm{ml}$ for testes at the maturation stages II and IX, 30-60 ml for testes 
at stages III to IV and VIII according to the testis size, and 70 to $100 \mathrm{ml}$ for testes at stages V-VII. They were otherwise resuspended in culture medium; this suspension was named "round testis cell suspension."

\section{Cell Separation}

Flow sedimentation at $\mathbf{1}$ g. The round testis cell suspension was separated on the basis of size into a population of cell clusters and a population containing mostly isolated cells (sedimentation at $1 \mathrm{~g}$ ) [Miller and Philips, 1969] by the following method. A small "Staput"' sedimentation chamber [Miller and Philips, 1969] $4 \mathrm{~cm}$ in diameter, $40 \mathrm{ml}$ in volume was filled with the first $40 \mathrm{ml}$ of a $90 \mathrm{ml}$ linear $1-3 \%$ BSA gradient in modified L15 medium (osmotic pressure adjusted to $300 \mathrm{mOsm}$ ). The chamber was modified to allow the arrival of the cell suspension to be fractionated just at the level of the surface of the gradient and its free outflow at the opposite side.

The testis cell suspension was pumped at $1 \mathrm{ml} / \mathrm{min}$ onto the surface of the gradient while the remaining gradient was pumped into the chamber at $0.3 \mathrm{ml} / \mathrm{min}$. The cell suspension devoid of cell clusters ("isolated cell population") was collected continuously. At the end of the separation, the cell clusters that sedimented on the bottom of the chamber were resuspended in the gradient remaining in the chamber, and this suspension ("cell clusters population") was collected. The two populations were centrifuged and washed by centrifugation (150g, 10 minutes) in modified L15 medium. If further cell separation was planned, each of the two pellets then was resuspended in 5 to $13 \mathrm{ml}$ of $1.5 \%$ BSA, $0.6 \%$ Ficoll in modified L15 medium. Otherwise, they were resuspended in culture medium.

Percoll gradient centrifugation. The various cell populations present in the "isolated cells" and "cell clusters" populations were separated according to cell density by centrifugation on $38 \mathrm{ml}$ linear $10-55 \%$ Percoll gradients (specific gravity: 1.016 to $1.070 \mathrm{~g} / \mathrm{ml}$ ). The gradients were prepared by the two-bottles method, with the aid of a peristaltic pump and stored in the cold until several days before use. Four $\mathrm{ml}$ of the cell suspensions were layered onto a gradient (one to three gradients per suspension; less than $0.5 \times 10^{8}$ round cells per gradient). The gradients were centrifuged at $800 \mathrm{~g}$ for 1 hour at $12^{\circ} \mathrm{C}$ and then collected in four fractions. Each fraction was immediately diluted three times with modified L15 medium and centrifuged at $200 \mathrm{~g}$ for 10 minutes. The pellets were washed once by centrifugation with $4 \mathrm{ml}$ modified L15 medium, the osmotic pressure of which was adjusted to 290 mOsm and then seeded in culture.

\section{Cell Culture}

Testis cell suspensions and fractions collected after the various steps of cell separation were cultured in plastic multiwell plates ( 6 or 24 wells) either coated with fibronectin [Imbenotte et al., 1985] or not. Usually, testis cell suspensions were seeded at a concentration between 1.5 and $35 \times 10^{6}$ round cells $/ \mathrm{ml}$ (somatic and germ cells larger than round spermatids), depending on the maturation stage of the testis, in order to take into account the dilution of the somatic cells by the germ cells. Suspensions enriched in somatic cells were seeded at a concentration around 2 to $5 \times$ $10^{6}$ round cells $/ \mathrm{ml}$. Culture was under air at $12^{\circ} \mathrm{C}$. The depth of the medium in the wells was about $2 \mathrm{~mm}$.

Routinely, culture medium was modified L15 medium either supplemented or not with $2 \%$ steroid-free Ultroser (Serum substitute, IBF, France). Highly purified 
salmon gonadotropin (s-GTH, a gift of Dr Breton) [Breton et al., 1978] was added at concentrations of $50-180 \mathrm{ng} / \mathrm{ml}$ or not added. Usually the medium was changed every second day.

\section{Cell Identification, Counting, and Viability}

In suspensions, spermatids and spermatozoa were identified easily by their small size and flagellum. Spermatogonia, which have a very large spherical nucleus [Billard, 1983], with one to four conspicuous nucleoli, and spermatocytes, which have a smaller nucleus containing heterogenous chromatin, were easier to identify when nuclei were prepared. The identification of the Sertoli cells was ascertained at the beginning by comparing their ultrastructure observed in situ with that at different steps after testis dissociation and in culture. They appeared in suspension as large cells with an ovoid nucleus. With testes at stages V-IX, they had a more or less vesiculous appearance, reflecting their in situ organization. At stages II, VIII, and IX spermatozoa usually were present in their cytoplasm. At every stage they enclosed some spermatogonia. In addition, they usually remained bound in clusters. Leydig cells and perilobular/myoid cells were identified in suspensions with electron microscopy by their characteristic ultrastructural features, but with the light microscope it has so far been impossible to recognize these cells among various round testis cells. Because their nuclei were similar to those of Sertoli cells, they were indistinguishable after nuclear preparation. Leydig cells were in fact identified by histochemical staining for $3 \beta$-hydroxysteroid deshydrogenase (3 $\beta$-HSD).

In the various cell suspensions, cells were counted using a hemocytometer on a phase contrast microscope. The different somatic cells, spermatogonia, and spermatocytes, when present, usually were counted together as "round cells." An alternative method to cell counting was to prepare the nuclei with $0.4 \%$ hexadecyltrimethylammonium bromide plus $1 \mathrm{mM} \mathrm{CaCl}_{2}$ [Loir and Wyrobek, 1972]. This method allowed to cells to be counted even when they were in clusters. When preceded by a hypotonic treatment, as suggested by Butler [1984], cells could be counted in culture plates after they had adhered to the plastic.

Cell viability was determined by the $0.2 \%$ erythrosine $\mathrm{B}$ dye exclusion test [Philips, 1973].

\section{Identification of the Steroidogenic Cells}

Histochemical staining for $3 \beta-H S D$ was performed by a modification of the method of Levy et al. [1959]. Cells in suspension ( $0.3 \mathrm{ml}$ aliquots) were centrifuged $(150 \mathrm{~g}, 8 \mathrm{~min})$, pellets resuspended in one or two drops $6 \%$ dextran $(\mathrm{W} / \mathrm{V})$ in phosphate buffered saline (PBS), and frozen at $-70^{\circ} \mathrm{C}$ for up to 2 weeks. Cells attached to plastic were washed once with PBS and then covered with the reaction mixture modified to omit the steroid, the dimethyl sulfoxide (DMSO) concentration (10\%) being kept unchanged. After 10 minutes at $2^{\circ} \mathrm{C}$, most of the liquid was removed and the plates were frozen at $-70^{\circ} \mathrm{C}$. Cell suspensions and plates were thawed at room temperature, and $300 \mu \mathrm{l}$ of reaction mixture were added to cells in suspension while the attached cells were covered with the mixture. Both were incubated for 45 minutes at $37^{\circ} \mathrm{C}$. The percentage of violet-stained cells was either immediately estimated or the reaction stopped by addition of ethanol ( $20 \%$ final concentration); and then the cells were stored in cold phosphate buffer. Percentages 
of Leydig cells in cell suspensions were used to determine the number of Leydig cells per $\mathrm{ml}$ after the total cell counts.

The reaction mixture consisted of 1 volume of $1 \mathrm{mg} 5 \beta$-androstan-3 $\beta$-ol-17-one (etiocholan-3 $\beta$-ol-17-one, Sigma)/ml DMSO, 1 volume $2 \mathrm{mg}$ tetranitro blue tetrazolium (Sigma)/ml $\mathrm{H}_{2} \mathrm{O}, 4$ volumes $0.1 \mathrm{M} \mathrm{pH} 7.2$ phosphate buffer, and 4 volumes 6 mg NAD (Sigma)/ml phosphate buffer. The steroid was omitted from the control samples.

\section{Electron Microscopy}

Cells in suspension or attached to plastic were washed in Earle's salt solution. They were fixed for 1 hour in $2.5 \%$ glutaraldehyde in $0.1 \mathrm{M}$ cacodylate buffer $\mathrm{pH}$ 7.4 , containing $5 \mathrm{mM} \mathrm{CaCl}_{2}$ then washed twice in this solution. They were postfixed

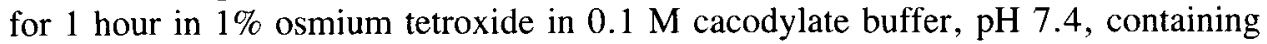
$1.5 \%$ potassium ferricyanide and $1 \%$ sucrose and then washed in $0.1 \mathrm{M}$ cacodylate buffer. The attached cells were delicately freed by scraping. Cells in suspension and scraped cells were embedded in 2\% agar before being dehydrated in acetone and embedded in a mixture of Epon-araldite. Sections were double-stained and observed with a $100 \mathrm{CX}$ Jeol electron microscope.

\section{Steroid Radioimmuno Assays}

Progesterone was assayed in culture medium and in cells after extraction with hexane, according to Lecouteux et al. [1985]. The radioimmunoassay for $17 \alpha$, $20 \beta$ dihydroprogesterone $(17 \alpha 20 \beta-O H P)$ was performed as described by Fostier et al. [1981] and Fostier and Jalabert [1986]. Eleven ketotestosterone (11-KT) was assayed according to Fostier et al. [1982]. These two steroids were extracted from culture medium with ethylacetate:cyclohexane (50:50). The main crossreactivities, expressed as the ratio of the mass of the assayed steroid to the mass of steroid required to decrease the bound level of the tracer to half its value without competitors were the following: progesterone with $17 \alpha$ - and $20 \beta-O H P,<5 \% ; 17 \alpha, 20 \beta-O H P$ with $20 \beta-O H P, 2 \% ; 17 \alpha, 20 \alpha-\mathrm{OHP}, 1 \% ; 11-\mathrm{KT}$ with testosterone, $1.1 \%$; adrenosterone, $1 \% ; 11 \beta$-hydroxytestosterone, $1 \%$.

\section{RESULTS}

\section{Dissociation of Testis}

Various proteolytic enzymes were used - trypsin, collagenase, pronase, hyaluronidase - at several concentrations, at 5,12 , and $16^{\circ} \mathrm{C}$, either alone or in association. Collagenase used at $0.8 \mathrm{mg} / \mathrm{ml}$ at $12^{\circ} \mathrm{C}$ was the most effective enzyme. Pronase was also effective, especially in favoring the dispersion of spermatozoa aggregates and their release from Sertoli cell clusters, but it was somewhat toxic and depressed the 11-KT secretion unless used at concentrations below $0.2 \mathrm{mg} / \mathrm{ml}$ for only 1 hour at the beginning of testis dissociation. Suppressing both $\mathrm{Ca}++$ and $\mathrm{Mg}++$ decreased cell viability. However, suppression of just $\mathrm{Ca}++$ did not affect cell viability but speeded up testis dissociation 2.5 times. Enzyme treatment of testis fragments, even when they were small, appeared to be rather inefficient. By contrast, perfusion with collagenase for 4 to 7 hours almost completely dispersed a testis (apart from the two extremities that were not perfused due to ligations securing the catheters).

After perfusion with enzymes, cell viability and dispersion were improved 
TABLE 1. Number of Round Testis Cells Larger than Spermatids and of Spermatozoa, per Gram of Testis and per Testis, as a Function of the Maturational Stages [Billard and Escaffre, 1975 ]*

\begin{tabular}{|c|c|c|c|c|c|c|c|c|c|c|}
\hline \multirow[b]{3}{*}{ Stage } & \multirow{2}{*}{\multicolumn{2}{|c|}{$\begin{array}{l}\text { Round Cells } \\
\times 10^{6}\end{array}$}} & \multirow{3}{*}{$\begin{array}{c}\text { testis } \\
\text { weight }\end{array}$} & \multirow[b]{3}{*}{$\mathrm{n}$} & \multirow{2}{*}{\multicolumn{2}{|c|}{$\begin{array}{c}\text { Spermatozoa } \\
\times 10^{10}\end{array}$}} & \multirow{3}{*}{$\begin{array}{c}\text { testis } \\
\text { weight }\end{array}$} & \multirow{3}{*}{$\begin{array}{c}\text { spermato. per } \\
\text { round cell }\end{array}$} & \multirow[b]{3}{*}{$\mathrm{n}$} & \multirow[b]{3}{*}{ Stage } \\
\hline & & & & & & & & & & \\
\hline & /gr & /testis & & & $\operatorname{lgr}$ & /testis & & & & \\
\hline \multirow[t]{2}{*}{ II } & & & & & \multirow{4}{*}{$\begin{array}{r}0.14 \\
\pm 0.13\end{array}$} & \multirow{4}{*}{$\begin{array}{r}0.20 \\
\pm 0.12\end{array}$} & \multirow{4}{*}{$\begin{array}{r}2.5 \\
\pm 1.8\end{array}$} & \multirow{4}{*}{$\begin{array}{r}13.5 \\
\pm 6\end{array}$} & \multirow{4}{*}{4} & \multirow[t]{3}{*}{ II } \\
\hline & & & & & & & & & & \\
\hline III & $\begin{array}{r}178 \\
\pm 98\end{array}$ & $\begin{array}{r}295 \\
\pm \quad 19\end{array}$ & $\begin{array}{r}2.5 \\
\pm 1.5\end{array}$ & 2 & & & & & & \\
\hline IV & 520 & 2942 & 4.9 & 5 & & & & & & \\
\hline V & \pm 297 & \pm 2690 & \pm 3.2 & & $\begin{array}{r}0.5 \\
\pm 0.2\end{array}$ & $\begin{array}{r}4.2 \\
\pm 0.5\end{array}$ & $\begin{array}{r}8.1 \\
\pm 2.9\end{array}$ & $\begin{array}{r}9 \\
\pm 1\end{array}$ & 2 & $\begin{array}{r}\text { V } \\
\text { VI }\end{array}$ \\
\hline VI & 295 & 3270 & 11 & 3 & & & & & & \\
\hline VII & \pm 131 & \pm 1090 & \pm 2.1 & & & & & & & VII \\
\hline VIIIa & $\begin{array}{r}12 \\
\pm 5\end{array}$ & $\begin{array}{r}144 \\
\pm 56\end{array}$ & $\begin{array}{l}13.9 \\
\pm 4\end{array}$ & 8 & $\begin{array}{r}3.9 \\
\pm 1.6\end{array}$ & $\begin{array}{r}51 \\
\pm 14\end{array}$ & $\begin{array}{r}14.1 \\
\pm 3.6\end{array}$ & $\begin{array}{r}4050 \\
\pm 1664\end{array}$ & 12 & VIIIa \\
\hline VIIIb & $\begin{array}{r}8 \\
\pm 4\end{array}$ & $\begin{array}{r}117 \\
\pm 89\end{array}$ & $\begin{array}{r}12.5 \\
\pm 4.5\end{array}$ & 2 & & & & & & VIIIb \\
\hline $\begin{array}{l}\text { IX } \\
\text { II }\end{array}$ & $\begin{array}{r}49 \\
+8\end{array}$ & $\begin{array}{r}60 \\
+\quad 16\end{array}$ & $\begin{array}{r}1.3 \\
\pm 0.5\end{array}$ & 3 & & & & & & $\begin{array}{r}\text { IX } \\
\text { II }\end{array}$ \\
\hline
\end{tabular}

$* \mathrm{n}=$ number of testes; mean values \pm standard error.

somewhat by overnight storing, with light shaking, in culture medium supplemented with $1 \%$ BSA. In agreement with the appearance of the cells, viability as assessed by the erythrosin dye exclusion test was $95-99 \%$. It is noteworthy that spermatids, when present, had a motile flagellum.

Quantitative estimations of the various cells obtained after dissociation of testes at different maturation stages are shown in Table 1. Spermatozoa from testes at stages II to IV were those that had not been eliminated during the last breeding season (residual spermatozoa).

Spermatozoa from mature testes (stages VII to IX) had a cell density equal to or higher than $1.065 \mathrm{~g} / \mathrm{ml}$, whereas most of the round testis cells had a lower density. After mixing the crude testis cell suspension with the SIP solution and centrifugation, about $98 \%$ of the round testis cells were gathered at the top of the tubes in a compact layer. In this way, with testes at stages VII-VIIIa, the number of spermatozoa per round cell was reduced by $484 \pm 60$ times $(n=5)$. In spite of this, for each round cell, there were up to 25 spermatozoa. With maturing testes (stages V and VI), only approximately $40 \%$ of the spermatids (reduction by $4 \pm 1$ times, $n=3$ ) and $90 \%$ of the spermatozoa (reduction by $11 \pm 5$ times, $n=3$ ) were removed (probably old spermatids, which have a lower cell density, were miscounted as spermatozoa). The removal of residual spermatozoa, (testes at stages VIIIb-III) from the round cell 

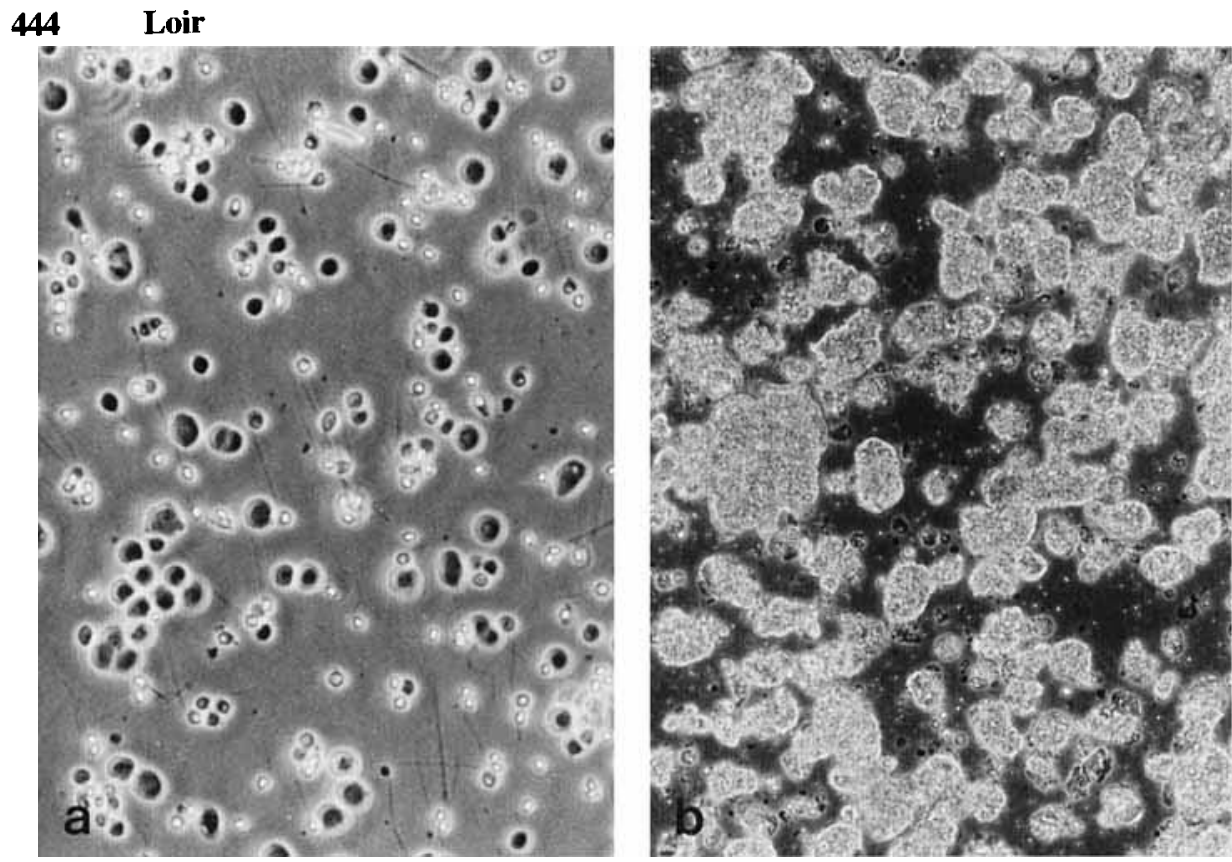

Fig. 1. Cell suspensions prepared from a stage VIIIa testis. Phase contrast microscopy. a: “isolated cell population"' $\times 350$. b: “cell cluster population". $\times 75$.

suspension was also less successful (reduction by 30 to 40 times), because a variable proportion of these old spermatozoa (up to $80 \%$ ) had a cell density equal to or lower than $1.065 \mathrm{~g} / \mathrm{ml}$. Fortunately, these residual spermatozoa were in rather low numbers in crude testis cell suspensions (Table 1).

\section{Preparation of Leydig and Sertoli Cell Populations}

Our previous attempts to separate trout Leydig and Sertoli cells either by sedimentation at $1 \mathrm{~g}$ [Miller and Philips, 1969] or by centrifugal elutriation [Grabske et al., 1975] were unsuccessful. This was due mainly to the fact that, after testis dissociation, 56 to $94 \%$ of Sertoli cells were obtained as large, essentially pure clusters, and between 30 and $95 \%$ of Leydig cells were obtained in clusters often mixed with myoid cells (fibroblast-like perilobular cells). These observations led to the following two-step strategy: 1) a separation by sedimentation at $1 \mathrm{~g}$ to obtain a population of cell clusters and a population of isolated cells and 2) a second separation by centrifugation on density gradients to separate Sertoli cells from Leydig cells either as clusters (first population) or eventually as isolated cells (second population).

To process a large volume of cell suspension quickly and to obtain just two distinct populations as undiluted as possible, we modified the "staput" sedimentation chamber and method. In this way $60 \mathrm{ml}$ of round cell suspension could be separated in 1 hour into a $80 \mathrm{ml}$ isolated cell population, together with a $40-\mathrm{ml}$ cell cluster population. Only a few clusters were still present in the isolated cell population which, in addition to a variable number of Leydig and Sertoli cells, essentially contained germ cells, macrophages, various blood cells, and spermatozoa (at most 40 per round cell) (Fig. 1a). Only some truly isolated round cells contaminated the cell 


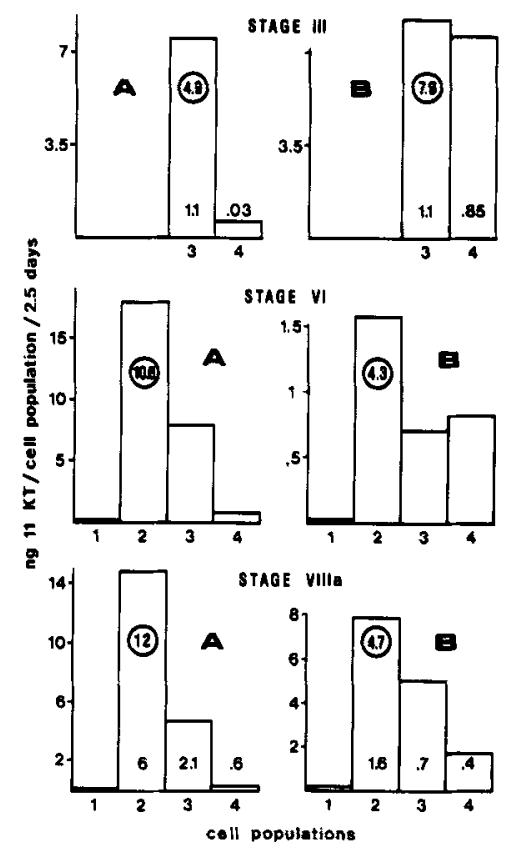

Fig. 2 Stimulated (120 ng s-GTH/ml) production of 11-KT by cell populations obtained after density gradient centrifugation of "cell cluster" (A) and "isolated cell", (B) populations prepared from three testes at various maturation stages. Culture:2.5 days on fibronectin-coated plastic. Density limits and cellular composition (for stages III and VIIIa) of the cell populations (see Table 2). Numbers at the bottom of the rectangles: numbers of Leydig cells $\left(\times 10^{6}\right)$ per cell population. Numbers of round cells $\left(\times 10^{6}\right)$ collected from the gradients were stage III, A: 13, B: 52; stage VI, A: 44, B: 49; stage VIIIa, A: 36, B: 8. Circled numbers represent the stimulated versus basal ratio of 11-KT secretion. For the corresponding round testis cell suspensions cultured in the same conditions, this ratio was equal to: stage III, 6; stage VI, 7.9; stage VIIIa, 6.8.

cluster population and, in addition to spermatogonia entrapped in Sertoli cells or gathered in small clusters, the contamination by other germ cells was usually low (Fig. 1b). However, this was not true with stage $V$ testes, because a high proportion of cysts containing spermatocytes and young spermatids were not disrupted by the previous enzymatic treatment and constituted most of the material collected in the cell cluster population.

At the end of this step, the yield for the total round cells was higher than $80 \%$ as compared with those present in the initial testis cell suspension.

After centrifugation on Percoll gradients of the cell cluster population or of the isolated cell population, 94-99.8\% of the Sertoli cells retrieved in gradients had a density lower than or equal to $1.048 \mathrm{~g} / \mathrm{ml}$, and according to the testis $55-87 \%$ of these cells had a density lower than or equal to $1.033 \mathrm{~g} / \mathrm{ml}$. The density of the Leydig cells at the different maturation stages appeared to be somewhat variable. With testes at stages V-VIII, 93 to $98 \%$ of the Leydig cells present in the cell cluster population had a density between 1.062 and $1.033 \mathrm{~g} / \mathrm{ml}$, and $65-75 \%$ had a density between 1.062 and $1.048 \mathrm{~g} / \mathrm{ml}$ (Fig. 2). With a testis at stage III, the mean Leydig cell density was slightly lower; $93 \%$ of the Leydig cell clusters were between 1.048 and 1.033 $\mathrm{g} / \mathrm{ml}$ (fig. 2). Furthermore, in testes undergoing spermatogenesis (stages III, V-VI), 
TABLE 2. Distribution of Sertoli Cells and Leydig Cells in Cell Populations Obtained After Density Gradient Centrifugation of the "Isolated Cells" and "Cell Clusters" Populations Prepared From One Stage VIIIa and One Stage III Testes*

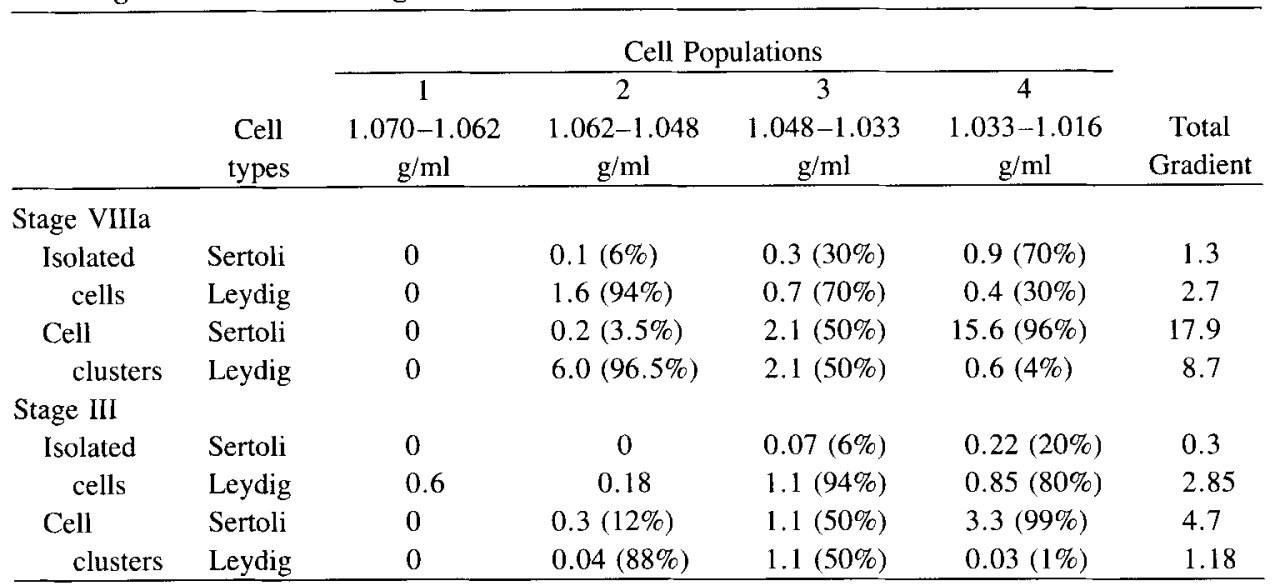

*Number of cells: $\times 10^{6}$. In parentheses: percentages of the total two cell types.

the Leydig cells present in the isolated cell population had a minimum density lower than that of the Leydig cells in clusters (Fig. 2), whereas up to 30\% of the isolated Leydig cells had a density between 1.033 and $1.017 \mathrm{~g} / \mathrm{ml}$ (Table 2). This was not observed in spermiating testes.

As a consequence of the distribution of two somatic cell types in the density gradients, a nearly pure (in terms of somatic cell contamination) Sertoli cell population was obtained between 1.017 and $1.033 \mathrm{~g} / \mathrm{ml}$ (cell population 4) after centrifugation of the cell cluster populations. In all cases, the contamination by $3 \beta$-HSD-positive cells was estimated to be regularly under $5 \%$ and usually the 11 -KT assays confirmed the $3 \beta$-HSD test. It is to note that the $3 \beta-H S D$ activity of Sertoli cells has been checked carefully, after testis dissociation, in nine males. It was observed to be negative in seven animals, whereas in two spring-spawning males at maturation stage $\mathrm{V}$, it was slightly above the control. As mentioned above, the Sertoli cell populations also contained spermatogonia (on the average, one for four to five Sertoli cells), spermatozoa (maximum, seven for one Sertoli cell; the spermatozoa contaminating this population was less than $0.003 \%$ of the spermatozoa in the initial testis cell suspension) and for testes at stages III, VI, and VII, germ cells (on the average, one for three Sertoli cells). In the case of testes at stage V, no Sertoli cell was found in cell populations four and three, because most of the spermatocyte and spermatid cysts had remained undisrupted and had a high buoyant density. Depending on the testes, $20-39 \%$ of the Sertoli cells present in the initial testis cells suspension were obtained in this population, i.e., in our experiments, a minimum number of 0.35 $\times 10^{7}$ Sertoli cells (testis at stage III) and a maximum of $2.4 \times 10^{7}$ (stage VIII).

With mature and spermiating testes, a Leydig cell-enriched population was obtained between 1.048 and $1.062 \mathrm{~g} / \mathrm{ml}$ (cell population 2) after centrifugation of the cell cluster population. After $3 \beta$-HSD tests (confirmed by $11-\mathrm{KT}$ assays; Fig. 2) the concentration of functionally active Leydig cells in this population was high. As a mean, the contamination was 1 Sertoli per 25 Leydig cells, 1 spermatogonia per 11 Leydig cells, and 12 spermatozoa per Leydig cell. Contamination by myoid cells was 
TABLE 3. Numbers of Round Testis Cells Larger Than Spermatids, Spermatogonia, Sertoli Cells, Leydig Cells, and Spermatozoa in Three Trout Testes*

\begin{tabular}{|c|c|c|c|c|c|c|}
\hline & $\begin{array}{l}\text { Total } \\
\text { round cells } \\
\times 10^{6}\end{array}$ & $\begin{array}{l}\text { Sp. gonia } \\
\times 10^{6}\end{array}$ & $\begin{array}{l}\text { Sertoli cells } \\
\times 10^{6}\end{array}$ & $\begin{array}{l}\text { Leydig cells } \\
\quad \times 10^{6}\end{array}$ & $\begin{array}{c}\text { Spermatozoa } \\
\times 10^{10}\end{array}$ & $\begin{array}{c}\text { Spzoa } \\
/ \text { Sertoli cell }\end{array}$ \\
\hline $\begin{array}{l}\text { Stage III testis } \\
\quad \lg \end{array}$ & 276 & $\begin{array}{c}99 \\
(36 \%)\end{array}$ & $\begin{array}{c}12.5 \\
(4.5 \%)\end{array}$ & $\begin{array}{c}10 \\
(3.6 \%)\end{array}$ & $\begin{array}{c}0.33 \\
\text { (residual spz) }\end{array}$ & 265 \\
\hline $\begin{array}{l}\text { Stage VII-VIIIa testis } \\
15 \mathrm{~g}\end{array}$ & 187 & $\begin{array}{c}37 \\
(20 \%)\end{array}$ & $\begin{array}{l}75 \\
(50 \%)\end{array}$ & $\begin{array}{c}38 \\
(20 \%)\end{array}$ & 51 & 6800 \\
\hline $\begin{array}{l}\text { Stage VIIIa testis } \\
\quad 18 \mathrm{~g}\end{array}$ & 104 & $\begin{array}{c}22 \\
(21 \%)\end{array}$ & $\begin{array}{l}53 \\
(48 \%)\end{array}$ & $\begin{array}{c}24 \\
(23 \%)\end{array}$ & 88.5 & 16,600 \\
\hline
\end{tabular}

*Values inferred from cell and nuclei counts and from estimated proportions of $3 \beta$ HSD-positive cells at different steps of testis dissociation and cell separation. In parentheses: percentages of the total round cells corresponding to the considered cell type.

not estimated. With testes in spermatogenesis (stages $\mathrm{V}$ and VI) cell population 2 was more or less contaminated by Sertoli cells and germ cells due to contamination by intact cysts. With a testis starting spermatogenesis (stage III), the more enriched Leydig cell population was obtained between 1.033 and $1.048 \mathrm{~g} / \mathrm{ml}$. Contamination by Sertoli cells then was near $50 \%$. Depending on the testes and on the proportion of Leydig cells obtained after dissociation as isolated cells, 16-29\% of the Leydig cells present in the initial testis cell suspension were obtained in the enriched population, i.e., between 0.15 (stage III) and $1.2 \times 10^{7}$ (stage VIII) Leydig cells.

For every testis, a second Leydig cell-enriched population was usually obtainable, between identical density values, after centrifugation of the isolated cell population, when at least $20 \%$ of the total Leydig cells were present in this population (Fig. 2). The purity of this second Leydig cell population in terms of Sertoli cell contamination was improved as usually few Sertoli cells usually were present in the isolated cell population. On the contrary, contamination by spermatogonia, various somatic cells or blood cells, and especially spermatocytes and spermatids with testes in spermatogenesis, was often very high. In the best conditions, the collection of such a population provided a total of twice as many Leydig cells.

It is noteworthy that in "cell cluster" gradients, a less enriched Leydig cell population (approximately 50\% Leydig cells and 50\% Sertoli cells) could be collected between the two Leydig cell and Sertoli cell populations $(1.033-1.048 \mathrm{~g} / \mathrm{ml}$; cell population 3 ). Sometimes another less enriched Leydig cell population also could be collected from the "isolated cell" gradients between the same density values.

The estimation of the number of certain cell types in two representative spermiating testes and one testis at stage III is shown in Table 3.

\section{Culture Medium Formulation and Culture Conditions}

Formulation of the culture medium and determination of the optimal culture conditions were studied with unfractionated round testis cell suspensions. The effects of changes on the Leydig cell metabolism were analysed by assaying their androgen (11-KT) secretion ability. Because no metabolic marker of Sertoli cells was known, only their ultrastructure, viability, and spreading ability were considered to be adequate parameters for checking the influence of changes in culture conditions on 
these cells. However, as these last parameters were not quantifiable, the Leydig cells were considered primarily to define the best culture parameters. Later, when Sertoli cell populations were cultured, it appeared that the chosen conditions were as good for these cells as for Leydig cells.

Several culture media were studied: minimal Eagle medium, M 199 medium, M 199/NCTC 135 (1/1) medium, NCTC 135/Ham F12 (1/1) medium with either Hanks or Earle balanced salts and containing $15 \mathrm{mM}$ Hepes, $4 \mathrm{mM}$ Sodium bicarbonate, 4 $\mathrm{mM} \mathrm{Na}$ lactate, $2 \mathrm{mM}$ glutamine and vitamins A, E, and C, Leibovitz L15 medium without sodium bicarbonate. No significant differences were observed among the first four media. In contrast, when Leibovitz L15 medium was compared, for example, with the complex and rich NCTC 135/F12 medium, the stimulated (100 ng $\mathrm{s}-\mathrm{GTH} / \mathrm{ml}$ ) versus basal ratio of $11-\mathrm{KT}$ secretion was twice as high with L15 than with NCTC 135/F12 medium, after 2 days in culture.

Ultroser SF (steroid free) was preferred to fetal calf serum because of its consistent biological activity from batch to batch and because the addition of 1 volume of Ultroser is equivalent to 5 volumes of fetal calf serum. From the effects on cell viability, spreading, and morphology, a final concentration of $2 \%$ Ultroser was retained. Viable trout testis cells can be maintained in culture for 4-6 days without Ultroser, but in its presence their normal ultrastructure was better and preserved longer. The most conspicuous effect of Ultroser on the steroidogenic cells was to

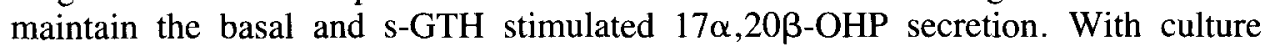
plates uncoated with fibronectin, Ultroser improved cell adhesion.

The effect of 1 and $10 \mu \mathrm{g}$ bovine insulin $/ \mathrm{ml}$ on steroidogenesis in the absence of Ultroser was studied. As no significant effect was observed, insulin was not routinely added to culture medium.

Light and electron microscopic observations indicated that Sertoli and Leydig cells are able to survive in suspension-type culture if they were not isolated, but were in clusters, and no significant difference was observed at the ultrastructural level with cells spread onto plastic. However, although the basal secretion of 11-KT was unaffected, the relative response to s-GTH was increased 1.5-fold if the cells had adhered and spread instead of remaining in suspension. For this reason and because medium changes were easier, cells were usually cultured in adhering layers. With Ultroser alone, the cells, especially Sertoli cells, adhered within 20 to 36 hours. On fibronectin-coated plastic, they adhered within 2 to 15 hours.

The depth of culture medium above the spread cells varied between 1.5 and 10 $\mathrm{mm}$. Studies of the viability and morphology of the testis cells suggested that the depth must not be higher than $2 \mathrm{~mm}$. In this condition, if the proportion of oxygen was increased (to around $70 \%$ ), there was no improvement of cell activity but rather the 11-KT secretion was somewhat decreased (1.2-fold).

\section{Cell Viability in Culture}

Cells were cultured for 10-15 days. Their viability, morphology, and ultrastructure were monitored during this period. No other criterion was used to check the integrity and metabolic state of Sertoli cells. The steroidogenic activity of Leydig cells was considered.

When seeded in fibronectin-coated wells, Sertoli cells adhered rapidly and began to spread immediately. They appeared characteristically epithelioid in morphology (Fig. 3a). Sertoli cell clusters did not spread rapidly: $0.4 \times 10^{6}$ Sertoli 

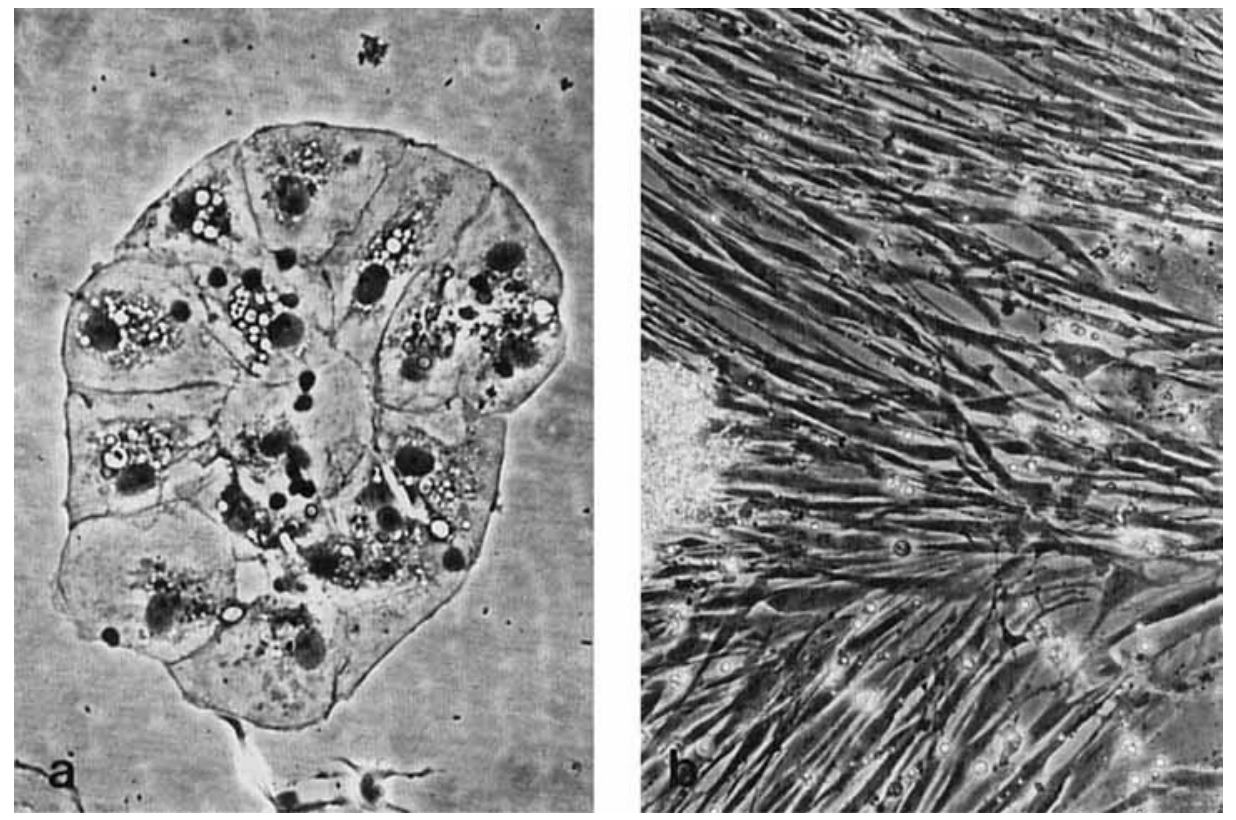

Fig. 3. Somatic cells spread on fibronectin-coated plastic. Phase contrast microscopy. a: a Sertoli cell cluster, stage VIIIa testis, 4 days in culture, $\times 320$. b: Leydig cells, stage III testis, 15 days in culture, $\times 75$.

cells $/ \mathrm{cm}^{2}$ needed about 10 days to occupy the entire area. These cells kept their ultrastructural features through at least 10 days (Fig. 4).

Whether isolated or in clusters, most of the Leydig cells seeded onto fibronectin-coated plastic adhered in less than 15 hours. Leydig cell clusters spread rather slowly. They then displayed a fibroblastoid morphology similar to that of

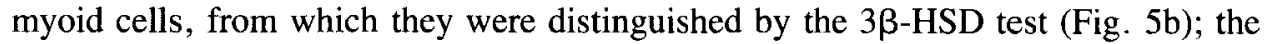
myoid cells being unstained.

When cultured in the presence of $2 \%$ Ultroser, the Leydig cells kept a characteristic ultrastructure of steroid-producing cells during the first 4 to 6 days (Fig. 9). After 6 days some changes in the ultrastructure progressively became apparent. After 12 and 15 days, fibroblastoid cells were still $3 \beta-H S D$ positive.

For at least 11 days, progesterone secretion (output in the medium plus cell content) by round testis cell suspensions either slowly increased or remained constant according to the testes (Fig. 8). Throughout the first 12 days in culture in the presence of Ultroser, the secretion of $17 \alpha, 20 \beta-O H P$ increased for about 7 days and then remained constant or decreased slightly (Fig. 7). This occurred also in isolated cell populations and for Leydig cell populations.

After the enzymatic treatment, the Leydig cells displayed a high $3 \beta-\mathrm{HSD}$ activity (Fig. 5a), and they could be stimulated in dose-dependent manner by s-GTH, except when they were prepared from testes at the end of the spermiation period (stage VIIIb and especially stage IX) (Fig. 6). When mature testes were perfused overnight with collagenase, the stimulated $(100 \mathrm{ng} \mathrm{s}-\mathrm{GtH} / \mathrm{ml})$ versus the basal ratio of 11-KT secretion by the round testis cell suspension, after 1 or 2 days in culture, was lower than 5 (Figs. 6,7). When $\mathrm{Ca}^{2+}$ was suppressed from the enzymatic 

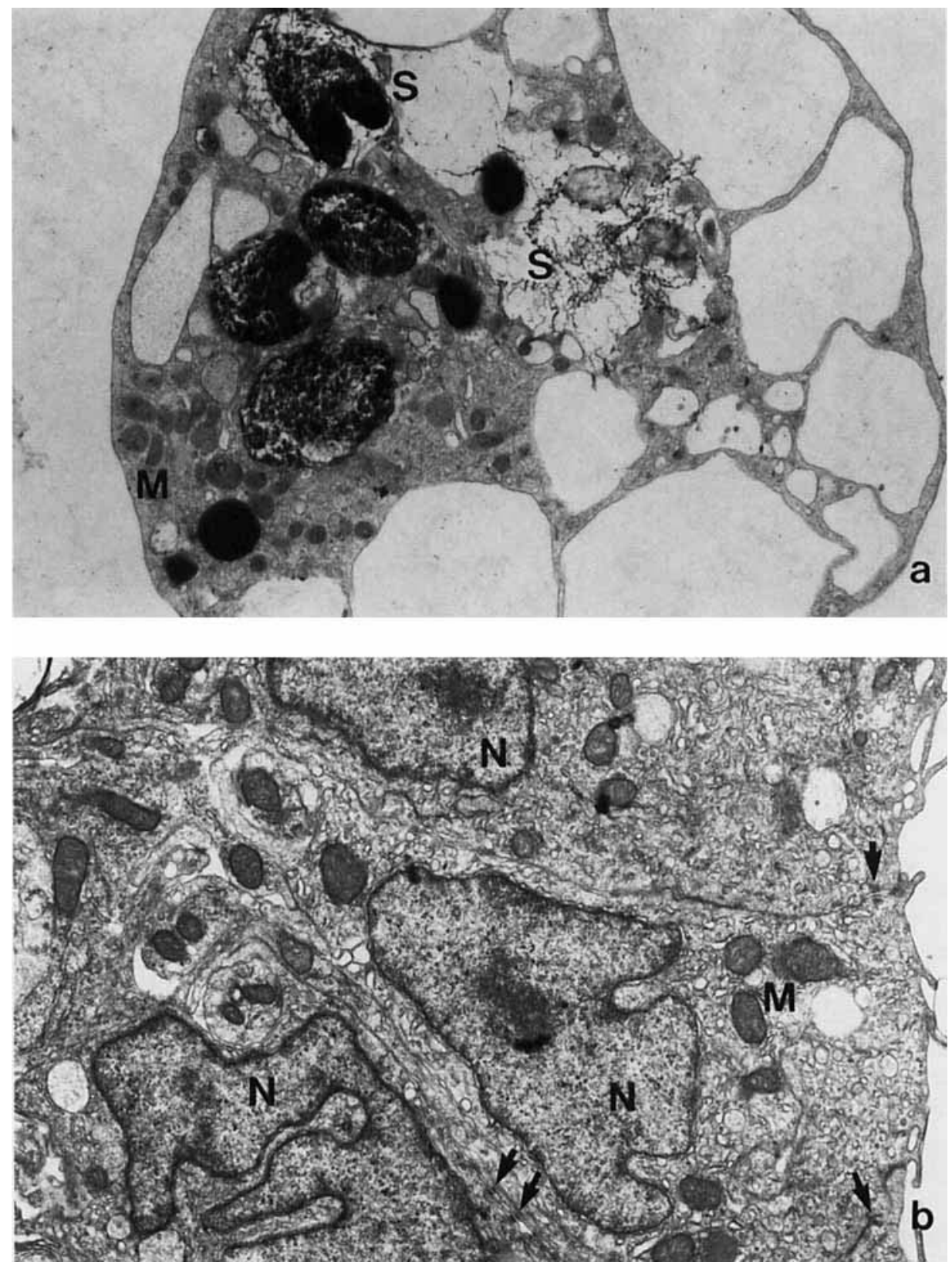

Fig. 4. Sertoli cells. a: after enzymatic dissociation of a stage VIIIa testis. At this stage, Sertoli cells are "vacuolated" (spermatogonia sometimes are entrapped in these "vacuoles") and contain phagocytosed spermatozoa (S). $\times 7000$. b: prepared from a stage VIIIb-IX testis after 7 days culture in suspension. Desmosomes (arrows) are present at the periphery of the cluster but also inside. The nuclear membrane (N: nucleus) is deeply invaginated. The mitochondria (M) have a dark matrix and lamellar cristae. $\times 10,800$. 

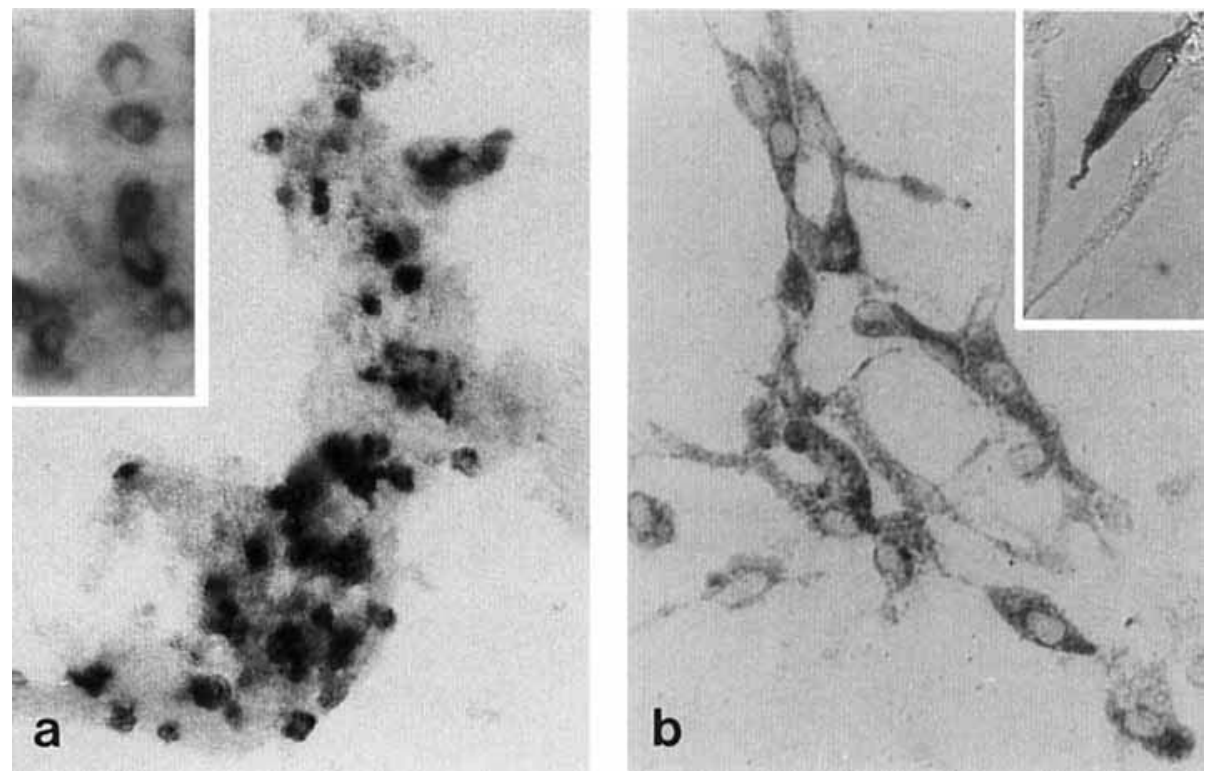

Fig. 5. Light micrographs of $3 \beta$-hydroxysteroid dehydrogenase staining of cells in the Leydig cell population obtained after density gradient centrifugation of the cell cluster population, prepared from a stage VIIIa testis. a: after centrifugation, $\times 80$. Inset: note that the nuclei are unstained, $\times 360$. b: after 2.5 days in culture, $\times 400$. Inset: two fibroblast-like cells (myoid cells ?) are unstained. $\times 380$.

solution and the testes were perfused for only 5-6 hours, this ratio was higher than 6 (Fig. 8).

When Leydig cell populations were cultured over 2 or 2.5 days, the GtHstimulated/basal ratio of 11-KT secretion 1) differed between the two populations, i.e., it was usually higher for the Leydig cell cluster population than for the isolated Leydig cell population (Fig. 2) except for one stage III testis; 2) the mean ratio for the two populations was near to that measured either for the corresponding testis cell suspension or for the unfractionated "isolated cell population" and "cell cluster population.",

The GtH-stimulated/basal ratio of $17 \alpha, 20 \beta-\mathrm{OHP}$ secretion was measured in three experiments. With a stage VII testis cell suspension, it was 1.4 after two days in culture (Fig. 7); the ratio was only 1.6 for $11-\mathrm{KT}$ secretion due to overnight enzymatic treatment. With a stage VIIla testis, the ratio was 1.5 for the unfractionated isolated cell population", and the Leydig cell (clusters) populations after 2.5 days in culture. With a stage III testis, no $17 \alpha, 20 \beta-O H P$ was secreted by the round testis cell suspension nor by the Leydig cell populations during the 2.5 first days in culture, but it was secreted later ( 2.5 to 11 days in culture).

\section{DISCUSSION}

Perfusion of trout testes with an enzymatic solution is technically more difficult than cutting the testes in small fragments, especially small testes with a narrow testicular vein. However, it was the only technique that completely dispersed the testes cells. Because of the small number of somatic cells that can be obtained from 

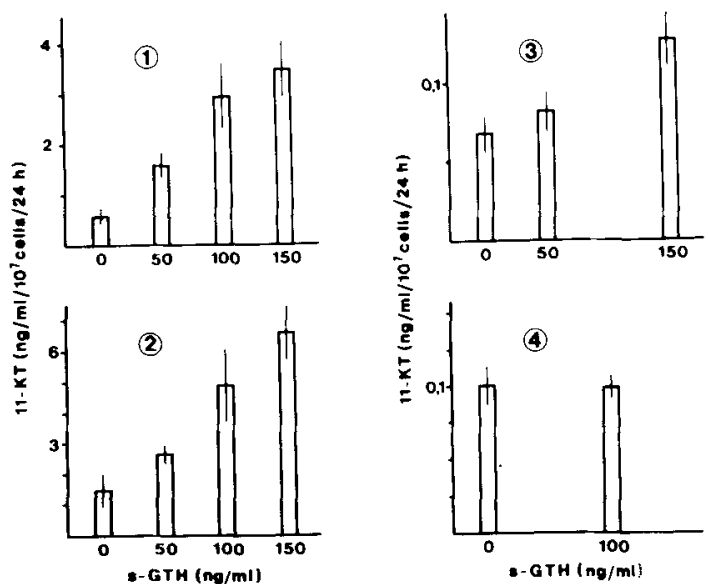

Fig. 6. Effect of increasing s-GtH concentrations on the 11-KT production by $10^{7}$ "round cells" obtained from testes at various maturation stages. 1: stage IV. 2: stage VI. 3: stage VIIIb. 4: stage IX. Enzymatic treatment: overnight in the presence of $\mathrm{Ca}++$. Culture in suspension for 24 hours. Mean of three wells \pm standard error.

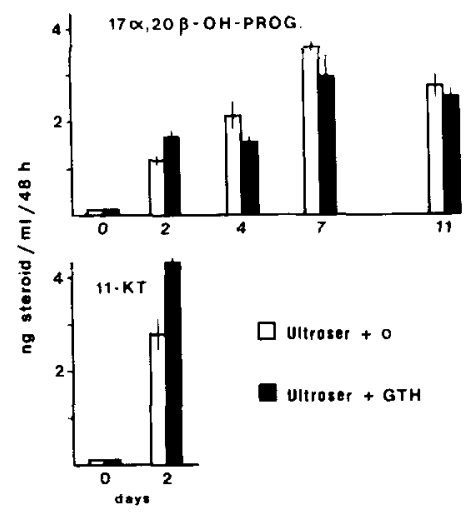

Fig. 7. Basal and s-GTH-stimulated $(100 \mathrm{ng} / \mathrm{ml})$ productions of $11-\mathrm{KT}$ after 2 days in culture and of $17 \alpha, 20 \beta-\mathrm{OH}$ progesterone during 11 days in culture, by a round testis cell suspension obtained from a stage VII testis. $4.4 \times 10^{6}$ round cells $/ \mathrm{ml}$ corresponding to about $0.7 \times 10^{6}$ Leydig cells $/ \mathrm{ml}$. Enzymatic treatment: overnight in the presence of $\mathrm{Ca}++$. Culture on fibronectin-coated plastic. Mean of three wells \pm standard error.

one testis, it was absolutely necessary to have as high a yield as possible of testis dissociated. The real yield, i.e., the number of somatic cells obtained as compared with the number of cells effectively present in the testis, was unknown. One observation suggests that it was high: the different solutions used throughout the first steps of testis dissociation contained almost no cell debris and nuclei. In addition, data obtained after testis dissociation can be compared with already published data, which, however, deal with germ cells and were obtained in brown trout [Billard, 1983]. If $20 \%$ of the round cells obtained from stage VIII testes (Table 3) were spermatogonia and if $140 \times 10^{6}$ round cells were obtained from such testes (Table 1), a mean of $28 \times 10^{6}$ spermatogonia (type A spermatogonia are present only during 


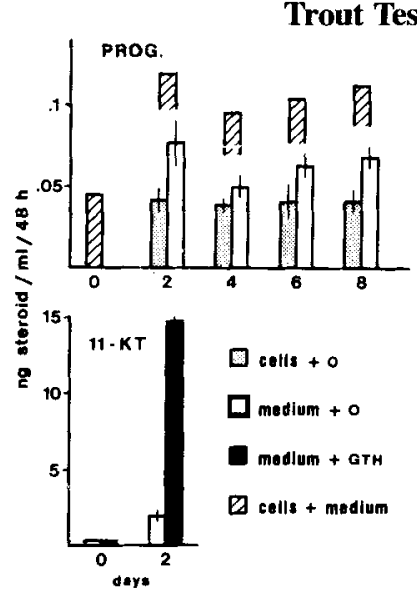

Fig. 8. Basal and s-GTH-stimulated ( $100 \mathrm{ng} / \mathrm{ml})$ production of $11-\mathrm{KT}$ after 2 days in culture and basal production (s-GTH-stimulated production was not significantly different) and cellular content of progesterone during 8 days in culture, by a round testis cell suspension prepared from a stage VII testis. $3.5 \times 10^{6}$ round cells $/ \mathrm{ml}$ corresponding to about $0.5 \times 10^{6}$ Leydig cells $/ \mathrm{ml}$. Enzymatic treatment: 5 hours. Culture on fibronectin-coated plastic. Mean of three wells \pm standard error.

this stage) would have been obtained per testis. According to Billard $34 \times 10^{6}$ spermatogonia type A should be present in one stage VIII testis in the brown trout.

Spermatozoa were present in variable amounts (up to 8500 per round cell) in almost all the testes used. Round testis cells from a mature testis were cultured for 13 days, either with a low amount of spermatozoa (eight per round cell) or with a high amount (180 per round cell). In the first culture, the ultrastructure of the somatic cells was well conserved, whereas in the second, mostly degenerating cells associated with decondensed sperm nuclei were observed. The major sperm protein is protamine. This protein is known to inhibit cell growth and proliferation by different mechanisms [Leibovich and Polverini, 1984; Huang et al., 1984]. Besides, according to Ueda et al. [1984], trout spermatozoa could convert $17 \alpha$ OHProgesterone to $17 \alpha, 20 \beta$-OHP. For these two reasons, it was necessary, especially for mature testes, to decrease as much as possible the contamination by spermatoazoa. Using the isodensity Percoll centrifugation method, this was reduced to just a few spermatozoa per Sertoli or Leydig cell. Finally, this residual contamination was of minor importance, as at the first change of culture medium, the somatic cells adhered to the plastic so that spermatozoa could be partly removed.

The high proportion of somatic cells obtained as clusters simplified the separation of these cells. Indeed, if the majority had been obtained as isolated cells, a separation on the basis of cell size would have been necessary either by sedimentation at $1 \mathrm{~g}$, which lasts several hours, or by centrifugal elutriation, which severely reduces cell viability and spreading ability. In contrast, it was easy to separate, rapidly and without deleterious effects, somatic cell clusters from the other isolated cells. Our separation strategy reduced the contamination by germ cells, macrophages, and lymphocytes of the two somatic cell (clusters) populations. Furthermore, with immature testes, the contamination of the Sertoli cell (clusters) population by isolated Leydig cells, which have a lower density than the Leydig cell clusters, was avoided. When isolated and clustered Leydig cells had different minimal densities, this could be due to the presence of myoid cells in the clusters, the myoid cells having a higher density than the Leydig cells; however, it cannot be 

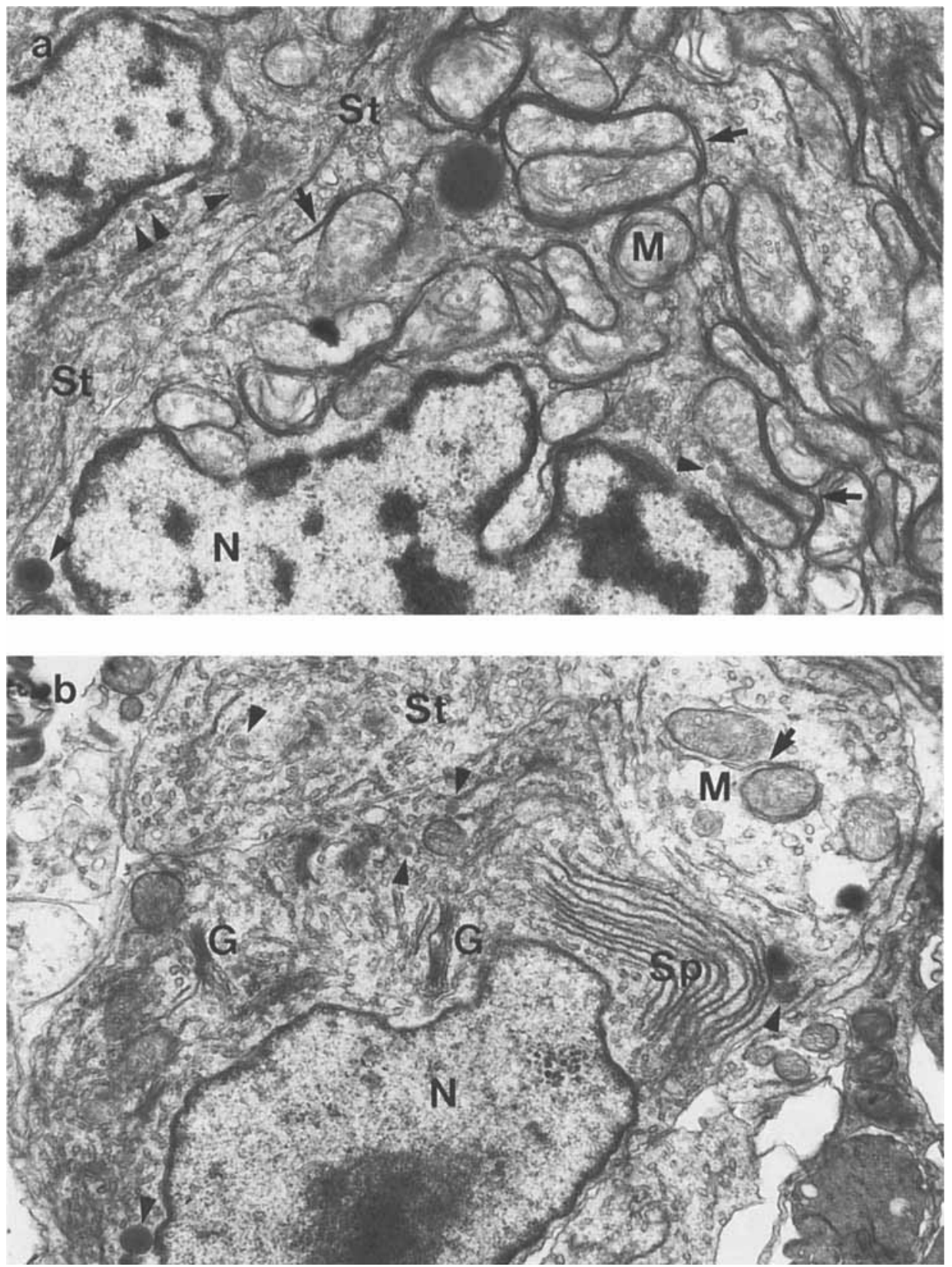

Fig. 9. Leydig cells obtained from a stage VIIla testis. a: after enzymatic treatment, $\times 14,600$. b: after 6 days in culture in suspension, $\times 13,000$. Note the presence of: mitochondria $(M)$ with tubular cristae and often surrounded by one or two smooth endoplasmic reticulum tubules (arrows); an abundant SER composed either of entwined tubules (St) or of large areas of closely spaced parallel arrays of tubules (Sp); some membrane-limited granules (arrowheads) and several profiles of the Golgi apparatus (G). After the enzymatic treatment the matrix of mitochondria is clearer than in situ and that observed few days later. $\mathrm{N}$ : nucleus. 
excluded that the density differences reflected intrinsic differences (metabolic stages, phases in activity cycle) among Leydig cells.

Whatever the maturation stage of the testes, the numbers of Leydig cells and Sertoli cells obtained in nearly pure populations always have been lower than $3 \times 10^{7}$ cells for one testis. At present it is not known how many Sertoli cells per well are necessary to study their metabolic activity and its control. For studies on the interactions of Sertoli cells with Leydig cell metabolism, enough Sertoli cells would be available, because twice as many Sertoli cells than Leydig cells were obtained. Basal steroid secretion of Leydig cells and its regulation could be measured adequately with $0.2 \times 10^{6}$ cells per well $\left(2 \mathrm{~cm}^{2}, 400 \mu l\right.$ culture medium). Approximately 24 wells could be seeded with a Leydig cell population (clusters) prepared from a mature testis. Of course, the other Leydig cell population prepared from the isolated cell population also could be used if the contamination by other cells is quantitatively and qualitatively known. With stage II and III testes, experiments with pure Leydig and Sertoli cell populations are more difficult, as only 6 to 10 wells could be seeded with each cell type.

Preparation of Sertoli cell populations from meiotic testes (stage V) has been unsuccessful, because at this stage most of these cells remained organized in intact cysts that contain either spermatocytes or spermatids. The buoyant density of these cysts is near that of interstitial cell clusters; thus, these cells and the cysts were obtained in the same fraction. If it were possible to separate them (by sedimentation at $1 \mathrm{~g}$ ?), this would allow investigations to be conducted on spermatogenetic cysts.

The organic composition of the culture medium was not apparently critical, which suggests that the specific requirements of the somatic trout testis cells in short-term primary cultures are rather simple. The beneficial effect of Leibovitz medium as compared with NCTC 135/F12 medium could be explained by the presence of deleterious factors in the latter medium; but it also could result from the absence of sodium bicarbonate in Leibovitz medium. It is known that salmonid cells are sensitive to concentrations of $\mathrm{CO}_{2}$ that are not inhibitory to mammalian cells [Fryer, 1965; Moon et al., 1985]. This agrees with the low bicarbonate concentrations present in fish blood [Albers, 1970].

Rainbow trout favors temperatures from 8 to $12^{\circ} \mathrm{C}$, and according to Manning and Kime [1985], the optimum temperature for formation of androgens in vitro is $10^{\circ} \mathrm{C}$. As enzyme efficiency on the one hand and cell growth on the other increase with temperature, testes and cells were processed at $12^{\circ} \mathrm{C}$. In fish, blood $\mathrm{pH}$ increases with decreasing temperature [Cameron, 1984; Moon et al., 1985]. A pH value of 7.7 was chosen, but adventitious $\mathrm{pH}$ variations during culture in the range 7.4-7.9 appear not to be critical. The osmotic pressure of the culture medium was adjusted to isotonicity with plasma (290 mOsm) (Prunet et al., 1985). However, a slight hypertonicity (315 mOsm) during enzymatic dissociation of testis appeared to improve cell viability slightly.

In culture, mammalian somatic testis cells require insulin and transferrin [De Philip et al., 1982]. No effect was observed whether trout testis cells were supplemented with insulin or not and also with transferrin (one experiment and one concentration: $10 \mu \mathrm{g} / \mathrm{ml}$ ). Several fish cell lines can grow without these two molecules in serum-free cultures [Shea and Berry, 1983]. Nevertheless, a hypoglycemic role has been proposed for insulin in fish [Moon et al., 1985].

Morphological and ultrastructural data and profiles of steroid secretion have shown that trout Sertoli and Leydig cells, obtained after enzymatic treatment and one 
or two separation steps, maintain a fully differentiated activity in culture over several days. The GtH-stimulated/basal ratio of 11-KT secretion was improved by shortening the enzymatic treatment. This suggests a detrimental effect of the enzymes when used over a long period. In the conditions we used routinely to disperse trout testes (4 to 6 hours in the presence of enzymes), this ratio was higher than 6 for the "round testis cell" suspensions prepared from stage VI to VIIIa testes. This is similar to that measured by Schulz and Blum [1987] and by Le Gac and Fostier, [1988], after incubations of testis fragments for 20 to 24 hours; thus, we consider that the enzymatic treatment did not affect significantly the steroldogenic response of the testis cells. On the other hand, our data suggest that after separation in Percoll gradients the responsiveness of Leydig cells to s-GtH was unchanged, as these cells are able to increase their 11-KT and testosterone [Le Gac and Loir, 1988] secretions to the same extent as before separation.

After Le Gac and Fostier [1987], 17 $\alpha, 20 \beta-O H P$ is secreted by testis fragments throughout the reproductive cycle. With mature testis fragments, the GtH-stimulated/ basal ratio of this steroid secretion is high [Ueda et al, 1984; Le Gac, unpublished results, ratio 11 to 26 ). Our results with $17 \alpha, 20 \beta-$ OHP secretion by various cell populations mostly devoid of spermatozoa differ from these data. They also disagree with Nagahama's suggestion that distribution of $20 \beta-H S D$ in testis is limited only to sperm [Nagahama, 1987]. The respective contribution of the testis somatic and germ cells in $17 \alpha, 20 \beta-O H P$ secretion is presently under investigation.

This work points out for the first time that it is quite possible to prepare and to culture trout Sertoli and Leydig cells. Although the preparation of these cells is somewhat laborious and the number of cells obtained is not always very high, it is now possible to study their metabolism and their reciprocal interactions throughout the reproductive cycle. This will, however, require the preliminary identification and purification of specific proteins secreted by Sertoli cells, which can be used as markers to check their differentiated activity. It is now possible to study, at the cellular level, the role and the mechanism of action of various molecules thought to control testicular steroidogenesis and spermatogenesis.

\section{ACKNOWLEDGMENTS}

This work was supported in part by a grant from the Institut National de la Recherche Agronomique (ATP 4433). We thank Drs F. Le Gac, A. Fostier, and D.H. Garnier for helpful discussions and advice during this work and Dr. B. Breton for the kind gift of s-GTH. We are indebted to Prof. R. Folliot for providing elecron microscopy facilities. We are grateful to Mrs. C. Cauty for her skillful assistance in the preparation of sections for EM, Mrs. B. Mourot, O. Marcuzzi, M. Bougoussa for expert technical assistance in a part of the study, Dr. D. Webb and J. Hall for help with the English, and J.Y. Lefeuvre for excellent assistance in preparing figures.

\section{REFERENCES}

Albers C (1970): Acid-base balance. In WS Hoar, DJ Randall (eds): "Fish Physiology IV." New York: Academic Press, pp 173-213.

Billard R (1983): A quantitative analysis of spermatogenesis in the trout, Salmo trutta fario. Cell Tissue Res 230:495-502.

Billard R, Escaffre AM (1975): Identification des stades de la spermatogenése de la truite fario d'après la morphologie des gonades et la spermiation. Bull Fr Pisci 256:111-118. 
Billard R, Fostier A, Weil C, Breton B (1982): Endocrine control of spermatogenesis in teleost fish. Can J Fish Aquat Sci 39:65-79.

Breton B, Prunet P, Reinaud P (1978): Sexual differences in salmon gonadotropin. Ann Biol Anim Biochim Biophys 18:759-765.

Butler WB (1984): Preparing nuclei from cells in monolayer cultures suitable for counting and following synchronized cells through the cell cycle. Anal Biochem 141:70-73.

Cameron, JN, (1984): Acid-base status of fish at different temperatures. Am J Physiol 246:452-459.

De Philip RM, Feldman M, Spruill WA, French FS, Kierszenbaum AL, (1982): The secretion of Androgen-binding protein and other proteins by rat Sertoli cells in culture: a structural and electrophoretic study. Ann NY Acad Sci 383:360-371.

Fostier A, Billard R, Breton B, Legendre M, Marlot S (1982): Plasma 11-oxotestosterone and gonadotropin during the beginning of spermiation in rainbow trout (Salmo gairdneri $\mathrm{R}$.). Gen Comp Endocrinol 46:428-434.

Fostier A, Jalabert B (1986): Steroidogenesis in rainbow trout (Salmo gairdneri) at various preovulatory stages: changes in plasma hormone levels and in vivo and in vitro responses of the ovary to salmon gonadotropin. Fish Physiol Biochem 2:87-99.

Fostier A, Jalabert B, Billard R, Breton B, Zohar Y (1983): The gonadal steroids. In WS Hoar, DJ Randall, EM Donaldson (eds): “Fish Physiology IX."' New York: Academic Press, pp 277-372.

Fostier A, Jalabert B, Campbell C, Terqui M, Breton B (1981): Cinétique de libération in vitro de la $17 \alpha$-hydroxy-20ßdihydroprogesterone par des follicules de truite arc-en-ciel, Salmo gairdneri. CR Acad Sci 292:777-780.

Fryer JL, Yusha A, Pilcher KS (1965): The in vitro cultivation of tissue and cells of pacific salmon and steelhead trout. Ann NY Acad Sci 126:566-586.

Grabske RJ, Lake S, Gledhill BL, Meistrich ML (1975): Centrifugal elutriation: separation of spermatogenic cells on the basis of sedimentation velocity. J Cell Physiol 86:177-190.

Harbin R (1984): Reproduction in male salmonids with special reference to the problems and control of maturation in fish culture. PhD thesis, University of Aston, Birmingham, AL, 483 pages.

Huang JS, Nishimura J, Huang SS, Deuel TF (1984): Protamine inhibits platelet derived growth factor receptor activity but not epidermal growth factor activity. J Cell Biochem 26:205-220.

Iatrou K, Spira AW, Dixon GH (1978): Protamine messenger RNA: evidence for early synthesis and accumulation during spermatogenesis in rainbow trout. Dev Biol 64:82-98.

Idler DR, Ng TB (1983): Teleost gonadotropins: isolation, biochemistry and function. In WS Hoar, DJ Randall, EM Donaldson (eds): “Fish Physiology IX.' New York: Academic Press, pp 187-221.

Imbenotte J, Verger C, Sassa S (1985): Modulation of cell attachment to culture support by pH, fibronection, hemin and cobalt protoporphyrin. J Cell Physiol 124:358-362.

Lecouteux A, Garnier DH, Bassez T, Joly J (1985): Seasonal variations of androgens, estrogens and progesterone in the different lobules of the testis and in the plasma of Salamandra salamandra. Gen Comp Endocrinol 58:211-221.

Le Gac F, Fostier A (1987): Binding and action of s-GtH on rainbow trout testis at various stages of gametogenesis. Third International Symposium on Reproductive Physiology of Fish, St John's. Abstract 119.

Le Gac F, Fostier A (1988): Relationship between stage of spermatogenesis, testicular responsiveness to gonadotropin hormone (GEH) and number of GEH receptors in the testis of a teleost (Salmo gairdneri). 5th European workshop on the molecular and cellular endocrinology of the testis, Brighton. Abstract F25.

Le Gac F, Loir M (1988): Control of testis function in fish: in vitro studies of gonadotropic regulation in the trout (Salmo gairdneri). Reprod Nutr Dev., in press,

Leibovich SJ, Polverini PJ (1984); Protamine sulfate inhibition of serum-induced mitogenic responses: differential effects on normal and neoplastic cells. J Natl Cancer Inst 73:1337-1347.

Levy H, Deane HW, Rubin BL (1959): Visualisation of steroid -3 -ol dehydrogenase activity in tissues of intact and hypophysectomised rats. Endocrinology 65:933-943.

Loir M, Wyrobek A (1972): Density separation of mouse spermatid nuclei. Exp Cell Res 75:261-265.

Manning NJ, Kime DE (1985): The effect of temperature on testicular steroid production in the rainbow trout, Salmo gairdneri, in vivo and in vitro. Gen Comp Endocrinol 57:377-382.

Miller RG, Phillips RA (1969): Separation of cells by velocity sedimentation. J Cell Physiol 73:191-202.

Moon TW, Walsh PJ, Mommsen TP (1985): Fish hepatocytes: a model metabolic system. Can J Fish Aquat Sci 42:1772-1782. 
Nagahama Y (1987): Gonadotropin action on gametogenesis and steroidogenesis in teleost gonad. Zool Sci 4:209-222.

Phillips HJ (1973): Dye exclusion tests for cell viability. In RF Kruse, MK Patterson (eds): "Tissue culture." New York: Academic Press, pp 406-408.

Prunet P, Boeuf G, Houdebine LM (1985): Plasma and pituitary prolactin levels in rainbow trout during adaptation to different salinities. J Exp Zool 235:187-196.

Schulz R, Blum V (1987): Gonadotropin stimulated androgen secretion of rainbow trout (Salmo gairdneri Richardson) testis in vitro. Comp Biochem Physiol 88A:49-54.

Shea TB, Berry ES (1983): A serum-free medium that supports the growth of piscine cell cultures. In Vitro 19:818-824.

Tahka KM (1986): Current aspects of Leydig cell function and its regulation. J Reprod Fertil 78:367-380.

Ueda H, Kambegawa A, Nagahama Y (1984): In vitro 11-ketotestosterone and $17 \alpha, 20 \beta$-dihydroxy-4pregnen-3-one production by testicular fragments and isolated sperm of rainbow trout, Salmo gairdneri. I Exp Zool 231:435-439. 